ISSN 2089-8673

Jurnal Nasional Pendidikan Teknik Informatika (JANAPATI)

Volume 1, Nomor 3, Desember 2012

\title{
Mendesain Model Pembelajaran Dengan Menggunakan \\ e-Learning: Suatu Kajian Teoretik
}

Oleh:

$\underline{\text { I Wayan Sukra Warpala }}$

Kegiatan atau praktik belajar dan pembelajaran yang berlangsung di sekolahsekolah pada saat ini dipengaruhi oleh dua aliran psikologi, yaitu aliran behavioristik dan kognitif. Teori belajar behavioristik dengan model hubungan stimulus - responnya, mendudukkan orang yang belajar sebagai individu yang pasif. Proses belajar ditempuh dengan cara drill atau pembiasaan-pembiasaan yang disertai dengan reinforcement untuk membentuk perilaku (sebagai hasil belajar). Di sisi lain, aliran kognitif berupaya menjelaskan proses belajar dan pembelajaran dengan berlandaskan pada peristiwaperistiwa internal pebelajar. Dengan kata lain, teori belajar kognitif lebih banyak mendeskripsikan apa yang terjadi dalam diri seseorang ketika ia belajar. Proses belajar dan pembelajaran dipandang sebagai suatu proses pemaknaan informasi baru atau pengalaman baru dengan jalan mengaitkannya dengan struktur informasi yang telah dimiliki. Proses belajar terjadi lebih banyak ditentukan oleh motivasi internal individu pebelajar dan keaktifan inilah menjadi unsur utama yang akan menentukan keberhasilan belajar dan pembelajaran.

Dari beberapa kajian teoretik dan penelitian (Brooks \& Brooks, 1993; Duffy \& Jonassen, 1992; Jonassen, 1999; Wilson, 1996) terungkap bahwa pembelajaran yang efektif, interaktif, dan menarik bagi pebelajar adalah proses pembelajaran yang dilandasi oleh paradigma konstruktivisme. Dalam implementasinya, pebelajar lebih banyak berinteraksi secara aktif dengan lingkungan belajarnya. Dari sini, secara berkesinambungan pebelajar berupaya mengakomodasi berbagai informasi dan pengalaman yang logis dan koheren. Tujuan pembelajaran atau kriteria keberhasilan harus dinegosiasikan dengan pebelajar, aktivitas yang direncanakan muncul dari dalam konteks dunia kehidupan nyata pebelajar, dan perlunya kolaborasi antar pebelajar dalam konstruksi sosial. Pandangan-pandangan inilah yang telah mempengaruhi teori dan praktik teknologi pembelajaran dewasa ini. 
ISSN 2089-8673

Jurnal Nasional Pendidikan Teknik Informatika (JANAPATI)

Volume 1, Nomor 3, Desember 2012

Secara intelektual, pengaruh teori dan pandangan tersebut telah berfungsi sebagai konteks untuk pertumbuhan teknologi pembelajaran. Kekuatan-kekuatan ini dengan kedisiplinan agendanya masing-masing telah membentuk pendekatan umum ke arah penyusunan penelitian dan teori, teknik, dan prinsip-prinsip praktik dalam bidang teknologi pembelajaran. Dari perspektif paradigma Teknologi Pembelajaran 1994, arah pendekatan umum tersebut tidak mustahil dapat terwujud, mengingat definisi dan kawasan yang dimilikinya berorientasi sistematis. Secara implisit, definisi Teknologi Pembelajaran 1994 menekankan bahwa teknologi pembelajaran merupakan proses desain dan pengembangan yang komprehensif dan digunakan untuk memecahkan masalah belajar dan pembelajaran (Seels \& Richey, 1994).

Berdasarkan paparan di atas, ada beberapa permasalahan belajar dan pembelajaran yang harus dijawab. Salah satunya adalah bagaimanakah merancang model desain atau program pembelajaran yang menggabungkan pandangan-pandangan yang bermanfaat mengenai kondisi pembelajaran secara sistematis? Dari fenomena tersebut, maka dalam tulisan ini akan dipaparkan mengenai electronik learning (e-learning) sebagai salah satu metode pembelajaran inovatif.

\section{e-Learning sebagai Metode Pembelajaran Inovatif}

Metode pembelajaran merupakan variabel pembelajaran yang lebih lanjut dapat diklasifikasikan menjadi tiga jenis, yaitu (1) strategi pengorganisasian, (2) strategi penyampaian, dan (3) strategi pengelolaan. Strategi pengorganisasian adalah metode untuk mengorganisasi isi bidang studi, yang mengacu pada suatu tindakan untuk pemilihan isi, penataan isi, pembuatan diagram, format, dan lain-lain yang setingkat. Strategi penyampaian adalah metode untuk menyampaikan pembelajaran kepada siswa (pebelajar) dan/atau untuk merespon masukan yang berasal dari siswa. Media pembelajaran merupakan bidang kajian utama dari strategi ini. Strategi pengelolaan adalah metode menata interaksi antara siswa dan variabel metode pembelajaran lainnya (variabel strategi pengorganisasian dan penyampaian isi).

Untuk selanjutnya, bahasan dalam tulisan ini akan memfokuskan pada implementasi e-learning sebagai strategi penyampaian isi pembelajaran. Dengan kata lain, bagaimana menggunakan e-learning untuk melaksanakan proses pembelajaran, yang 
ISSN 2089-8673

Jurnal Nasional Pendidikan Teknik Informatika (JANAPATI)

Volume 1, Nomor 3, Desember 2012

menyangkut di dalamnya (1) penyampaian isi pembelajaran kepada siswa dan (2) penyediaan informasi atau bahan-bahan yang diperlukan siswa untuk menampilkan unjuk kerjanya.

Istilah e-learning telah sering terdengar dalam beberapa tahun belakangan ini, tetapi belum banyak literatur (di Indonesia) yang membahas tuntas mengenai apa dan bagaimana e-learning tersebut. E-learning pada prinsipnya adalah proses belajar (pembelajaran) yang berbasis pada elektronik. Dalam hal ini, mengacu pada pemanfaatan berbagai piranti elektronik (utamanya komputer) sebagai media pembelajaran. Dari hasil sintesis beberapa literatur, penulis lain (de Caprariis, 2000; Harrison \& Bergen, 2000) mengistilahkannya dengan on-line learning. Kedua istilah ini memiliki penekanan yang sama pada fungsinya sebagai penyedia informasi atau bahan-bahan yang diperlukan dalam proses pembelajaran. Tetapi dalam hal fungsinya sebagai penyampaian isi pembelajaran kepada siswa memiliki sedikit perbedaan. Pada e-learning, proses pembelajaran "dirangsang/dimotori" oleh guru (teacher-student driven) dan didominasi oleh siswa (student-driven). Sedangkan pada on-line learning, proses pembelajaran hanya "dimotori" oleh siswa (student-driven). Dalam hal yang kedua ini, aktivitas belajar menempatkan siswa dalam posisi sentral dan sebagai pengambil keputusan dalam memecahkan masalah.

Mengacu pada posisi atau peran guru dan siswa dalam proses pembelajaran menggunakan e-learning ada dua jenis model desain pembelajaran yang akan ditawarkan. Model desain ini juga didasarkan pada kajian teoretik dan empirik (de Caprariis, 2000; Gabringer, 1996; Harrison \& Bergen, 2000; Javid, 2000; Jonassen, 1999; Savoie \& Hughes, 1994) yang berlandaskan pada desain lingkungan belajar konstruktivistik, yang didukung oleh pemodelan (modelling), pelatihan, (coaching), dan perancahan (scaffolding). Kedua model desain pembelajaran tersebut adalah (1) model semi rekursif dan (2) model rekursif.

\section{Model semi rekursif}

Model desain pembelajaran ini memadukan antara desain pembelajaran konvensional (tradisional) dengan pemanfaatan piranti elektronik sebagai media 
ISSN 2089-8673

Jurnal Nasional Pendidikan Teknik Informatika (JANAPATI)

Volume 1, Nomor 3, Desember 2012

pembelajaran. Dalam hal ini kita bisa membandingkan kelebihan dan kelemahan berbagai tipe media yang digunakan (misal: internet, electronic text book, data base, dan CD-R, atau media elektronik lainnya). Media elektronik yang digunakan bisa berupa informasi mengenai konten materi ajar dan/atau berupa aktivitas-aktivitas, seperti kuis (pertanyaan) dan tugas-tugas yang harus diselesaikan atau disempurnakan melalui internalisasi pengetahuan. Harapannya, dari kuis dan tugas-tugas tersebut menghasilkan keterampilan yang terintegrasi.

Model desain e-learning yang semi rekursif memiliki sifat-sifat (1) aktivitas yang terpisah; (2) perencanaan yang berperspektif tunggal, dengan sedikit mempertimbangkan pentingnya konteks dan konstruksi sosial; (3) perumusan tujuan berdasarkan analisis konten materi; dan (4) penetapan desain pesan berdasarkan rentangan kondisi rata-rata di mana sistem itu akan berfungsi.

Berdasarkan sifat-sifat model desain tersebut di atas, maka implementasi $e$ learning dapat dilakukan (disarankan) melalui tahapan-tahapan sebagai berikut: (1) Apersepsi; (2) Penjelasan konsep dan/atau Demonstrasi, (3) Eksplorasi; (4) Refleksi; dan (5) Evaluasi.

Apersepsi menyangkut di dalamnya aktivitas-aktivitas yang mengarah kepada terjadinya brain storming. Aktivitas belajar yang diharapkan dari tahapan in adalah meningkatkan perhatian dan menumbuhkan kesadaran terhadap masalah yang akan dipelajari, menstimulasi keingintahuan dan keinginan, melihat informasi-informasi yang relevan atau mengkonfrontasikan sesuatu yang ambigius.

Penjelasan konsep dan/atau demonstrasi menyangkut aktivitas guru menjelaskan ringkasan materi atau masalah yang akan dipelajari siswa. Jika diperlukan guru juga bisa melakukan demonstrasi. Peran guru pada tahapan ini juga diharapkan memotivasi terjadinya aktivitas belajar yang diarahkan untuk mengembangkan teknik-teknik pemrosesan informasi yang kreatif. Pada tahapan ini, peran guru sangat mendominasi proses pembelajaran.

Eksplorasi menyangkut kegiatan mengumpulkan data atau informasi dari berbagai jenis media, seperti CD-R, electronic data base, internet, dan media on-line lainnya. Aktivitas belajar yang juga termasuk tahapan ini adalah mengeksplorasi fenomenafenomena yang berhubungan dengan apa yang dipelajari. Dalam fase ini siswa bekerja 
ISSN 2089-8673

Jurnal Nasional Pendidikan Teknik Informatika (JANAPATI)

Volume 1, Nomor 3, Desember 2012

dalam kelompok-kelompok kecil sehingga terjadi diskusi dan berbagi pengetahuan atau keterampilan, yang sangat penting dalm proses belajar. Jadi, proses pembelajaran dalam tahapan ini didominasi oleh siswa.

Refleksi menyangkut aktivitas belajar berupa mengorganisasikan informasiinformasi yang telah diperoleh, berbagi ide, melakukan analisis, dan "mempertahankan" hasil yang diperoleh melalui kegiatan analisis dan sintesis. Dengan demikian akan terjadi konstruksi dan internaslisasi pengetahuan atau keterampilan yang diharapkan dari proses pembelajaran.

Evaluasi menyangkut kegiatan mengukur atau menilai unjuk kerja siswa melalui beberapa jenis asesmen yang sesuai (misalnya performance assessment).

\section{Model Rekursif}

Model desain pembelajaran ini sepenuhnya berpedoman pada teori belajar konstruktivistik. Selama proses pembelajaran, siswa menempati posisi sentral dan sebagai pengambil keputusan dalam memecahkan masalah yang dipelajarinya. Oleh karenanya, dalam mendesain e-learning yang rekursif, konten tidak bisa ditetapkan terlebih dahulu dalam proses desain. Akan tetapi, domain sentral atau inti dari pengetahuan (core knowledge) tersebut lah yang ditentukan. Artinya, pebelajar dirangsang untuk mencari domain pengetahuan atau informasi lainnya yang relevan dengan isu-isu yang ada. Jadi, pebelajar mampu membawa perspektif baru dan data baru mengenai isu-isu sehingga pebelajar terangsang untuk mencari pandangan-pandangan baru dan selalu mempertimbangkan sumber-sumber data alternatif terhadap domain konten pembelajaran.

Model desian ini memiliki sifat-sifat sebagai berikut (1) aktivitas yang terintegrasi; (2) perencanaan yang menggunakan perspektif majemuk, dengan mempertimbangkan pentingnya konteks dan konstruksi sosial; (3) perumusan tujuan berdasarkan pengetahuan dan/atau keterampilan awal pebelajar, (jika memungkinkan) dikaitkan dengan konteks kehidupan nyata pebelajar; (5) penggunaan desain pesan dengan berbagai variasi pilihan dan sebagai bagian integral dari proses; (6) sistem yang terbuka, yang memungkinkan terjadinya refleksi dan partisipasi pengguna; (7) penyediaan negosiasi sosial sebagai bagian integral dari disain material; (8) penggunaan mental 
models sebagai dasar desain pembelajaran, yang dapat menjembatani dunia pengetahuan, dunia belajar, dan dunia kerja.

Dengan karakteristik desain e-learning seperti di atas, maka untuk implementasinya dapat dilakukan dengan dua cara, yaitu: (1) media-mediated learning dan (2) on-line course. Untuk cara yang pertama, tindak pembelajaran dimediasi dengan berbagai jenis media elektronik (berbasis komputer). Sedangkan dengan cara kedua, segala aktivitas belajar, proses dan konten pembelajaran sepenuhnya on-line. Dalam hal ini kita memerlukan bantuan seorang ahli web site.

Dalam tindak pembelajaran, kedua cara tersebut dapat dilakukan melalui tahapantahapan pembelajaran sebagai berikut: (1) apersepsi (brain storming), (2) eksplorasi, (3) refleksi, (4) aplikasi, dan (5) evaluasi. Akankah kita mampu mendesain atau melakukan tindak pembelajaran seperti itu? Mari kita bersama-sama merenungkan masalah ini. Kajian terhadap teori-teori belajar yang berbasis konstruktivistik dan perkembangan teknologi informasi komunikasi selalu akan menjadi perhatian kita dalam menyikapi masalah ini. Segenap komponen yang terlibat dalam pembelajaran harus selalu menggali dan menggali bagaiman e-learning bisa didesain untuk mendukung proses belajar dan pembelajaran pada semua jenjang pendidikan.

\section{Faktor Penghambat Realisasi Potensi e-Learning}

Teori-teori atau pandangan belajar (pembelajaran) dan psikologi pendidikan telah berkembang cukup pesat. Penerimaan para praktisi pendidikan terhadap paradigma konstruktivisme telah mewarnai praktik teknik dan proses pembelajaran. Perkembangan teknologi komunikasi informasi juga semakin menunjukkan potensinya yang tinggi. Dari dukungan dan potensi yang ada ini, secara teoritis implementasi teknologi pembelajaran semakin terbuka. Tetapi yang terjadi adalah sebaliknya, pemanfaatan dukungan dan potensi tersebut tidaklah mudah seperti "membalikkan telapak tangan". Ada faktor-faktor pembatas yang berpengaruh terhadap realisasi potensi e-learning.

Faktor-faktor yang berpengaruh terhadap realisasi potensi e-learning di sekolah dapat digolongkan menjadi tiga kelompok, yaitu faktor pada tingkat sistem, faktor pada tingkat sekolah, dan faktor pada tingkat kelas sebagai tempat belajar. Ketiga kategori faktor tersebut dijelaskan dengan singkat, secara berturut-turut di bawah ini. 
Faktor pada tingkat sistem. Pada tingkat sistem, realisasi potensi e-learning dipengaruhi oleh tiga faktor, yaitu: (1) faktor ekonomi; implementasi inovasi teknologi, khususnya yang menyangkut hardware dan software, memerlukan biaya yang tidak sedikit. Dengan sistem pemerintahan dan sistem pendidikan yang ada di Indonesia rasanya sulit mewujudkan hal itu. Terlebih lagi dengan anggaran belanja dalam bidang pendidikan yang cukup rendah. Secara ekonomi kita tidak bisa merealisasi potensi teknologi tinggi atau bahkan "menengah" di sekolah; (2) faktor kebudayaan; beberapa negara (atau masyarakat) dengan latar budayanya menunjukkan "kecurigaan" terhadap teknologi dalam segala bentuknya. Teknologi tinggi diasosiasikan dengan budaya imperialisme. Dalam beberapa kasus, sekelompok masyarakat memandang teknologi baru sebagai ancaman bagi niali-nilai tradisional yang sudah diyakininya. Pandangan seperti inilah yang menghalangi penetrasi e-learning di sekolah, terutama di daerah-daerah pedesaan yang terpencil; dan (3) faktor kebijakan; implementasi e-learning secara sistemik memerlukan komitmen dari pemegang kebijakan, pimpinan, atau penyandang dana. Dengan kondisi ekonomi negara kita, kebijakan ke arah implementsi yang bersifat sistemik sangat sulit. Dan kenyataannya, implementasi hal serupa banyak dilakukan oleh penyandang dana dari luar, dan biasanya untuk proyek-proyek khusus yang sesuai denga keinginannya.

Faktor pada tingkat sekolah. Untuk kategori tigkat sekolah, realisasi potensi $e$ learning dipengaruhi oleh faktor-faktor sebagai berikut: (1) faktor aksesibilitas hardware dan software; biasanya para guru memiliki kecendrungan untuk menggunakan media yang hanya dapat diakses menurut pemahamannya. Mereka menghindari penggunaan media yang membutuhan kerja keras dan pengetahuan ekstra untuk memperoleh atau mengimplementasikannya; (2) faktor pemeliharaan hardware dan software; beberpa sekolah tidak memiliki teknis infrastruktur untuk menjaga fungsi alat-alat (media) yang dimilikinya. Permasalahan ini juga terjadi pada tingkat sistem. Pemerintah, agen, dan sekolah dengan segala keterbatasannya tidak bisa memelihara kesinambungan media atau program pendidikan. Sebagai contoh, program pendidikan televisi dari Stasiun TPI sudah "hilang dari peredaran". Dalam faktor ini juga menyangkut ketersediaan tenaga ahli (support personel) yang kurang di sekolah-sekolah; dan (3) faktor kurikulum; banyak sekolah kita menyelenggarakan proses pendidikan dengan penekanan pada pencapaian 
ISSN 2089-8673

Jurnal Nasional Pendidikan Teknik Informatika (JANAPATI)

Volume 1, Nomor 3, Desember 2012

target kurikulum. Di samping itu sekolah-sekolah kita berada di bawah tekanan pemerintah (pemegang kebijakan) dan sistem evaluasi nasional terstandar. Akibatnya, sekolah (dalam hal ini guru) menekankan pembelajarannya pada rote learning, pengetahuan verbal, dari pada visual dan pemahaman holistik.

Faktor pada tingkat kelas. Pada tingkat ini, realisasi potensi e-learning di pengaruhi oleh faktor-faktor, seperti: (1) faktor kompetensi guru; semakin kompleks teknologi yang digunakan, semakin tinggi tuntutan kompetensi yang harus dikuasai oleh guru. Para guru di sekolah-sekolah kita kurang mendapat pelatihan dalam bidang ni, termasuk juga para calon guru. Banyak guru di sekolah-sekolah kita yang "gagap teknologi”. Kondisi seperti ini menjadi faktor pembatas yang berpengaruh cukup besar untuk realisasi potensi teknologi dalam pembelajaran. (2) faktor karakteristik teknologi; setiap inovasi memiliki perpedaan profil dalam hubungannya dengan sifat/tujuan yang diinginkan oleh inovasi tersebut. Menurut Dorman (dalam Molenda, 1996) bahwa suatu inovasi yang ideal adalah yang mudah dipahami, tidak memerlukan biaya banyak, hasilnya sesuai harapan, dan konsisten dengan praktik sebelumnya. Tetapi kenyataannya bahwa inovasi yang harus diadopsi, sebagian besar mengharuskan perlunya sedikit perubahan yang disesuaikan dengan praktik yang konvensional dari para guru. Di sinilah letak faktor pembatas tersebut.

\section{Daftar Rujukan}

Brooks, J. G \& Brooks, M. G. 1993. In search of understanding: the case for constructivist classrooms. Virginia: Association for Supervision and Curriculum Development

de Caprariis, P., 2000. Constructivism in Online Learning: A View from the Science Faculty. Educational Technology, Vol. 40 (6), 41 - 45.

Duffy, T. \& Jonassen, D. 1992. Constructivism and the Technology of Instruction: A conversation. Hillsdale, New Jersey: Lawrence Erlbaum Associates, Publisher

Gabringer, R. S. 1996. Rich Environments for Active Learning. Dalam Jonassen, D. H (Ed): Handbook of Research for Educational Communications and Technology. New York: Simon \& Schuster Macmillan. p. 665-692.

Harrison, N \& Bergen, C., 2000. Some Design Strategies for Developing an Online Course. Educational Technology, Vol. 40 (1), 61 - 63.

Javid, M. A., 2000. A Suggested Model for a Working Cyberschool. Educational Technology, Vol. 40 (1), $57-60$.

Jonassen, D. H. 1999. Designing Constructivist Learning Environments. Dalam Reigeluth, C. M. (Ed): Instructional Design Theories and Models: A new paradigm of instructional theory, Vol. II. New Jersey: Lawrence Erlbaum Associates, Publisher. pp. 215-239. 
ISSN 2089-8673

Jurnal Nasional Pendidikan Teknik Informatika (JANAPATI)

Volume 1, Nomor 3, Desember 2012

Molenda, M. 1996. Educational Technology in Elementary and Secondary Education. Dalam Plomp, T. \& Ely, D (Eds): International Encyclopedia of Educational Technology, $2^{\text {nd }}$ ed. Cambridge, UK: Pergamon Elsevier Science Ltd

Savoie, J. M. \& Hughes, A. S. 1994. Problem-Based Learning as Classroom Solution. Educational Leadership, November 1994: p.54-57

Seels, B. B. \& Richey, R. C. 1994. Instructional Technology: The Definition and Domains of the Field. Washington, DC: Association for Educational Communications and Technology

Wilson, B. G (Ed). 1996. Constructivist Learning Environments: Case studies in instructional design. Englewood Cliffs, New Jersey: Educational Technology Publication, Inc 